\title{
Deoxyribonucleic Acid Reassociation in the Classification of Flavobacteria
}

\author{
By R. J. OWEN AND J. J. S. SNELL \\ National Collection of Type Cultures, Central Public Health Laboratory, \\ London $\mathrm{NW}_{9} \mathrm{SHT}$
}

(Received I 8 June 1975)

\begin{abstract}
SUMMARY
DNA-DNA reassociation studies showed that Flavobacterium meningosepticum strains had a genetic relatedness of 91 to $100 \%$ with inter-strain duplexes having high thermal stabilities. The only exception, strain NCTCIOOI6, had an average relatedness of only $43 \%$ to other strains of $F$. meningosepticum. The apparent divergence in DNA base sequence of this strain was reflected in the structural differences of some enzymes. There was a gradation of DNA relatedness among the Flavobacterium group II-b strains, but three strains were sufficiently related to constitute a species. Low levels of genetic relatedness were confirmed between $F$. meningosepticum and strains of Flavobacterium group II-b, group II-f, F. aquatile, $F$. breve, $F$. heparinum, $F$. pectinovorum, $F$. odoratum and Moraxella saccharolytica. All strains had base compositions in the range 32 to $46 \%$ guanine plus cytosine. The genome sizes of representative strains of F. meningosepticum and Flavobacterium group II-b were $2.50 \times 10^{9}$ to $3.52 \times 10^{9}$ daltons, whereas the group II-f strains had smaller genomes of $\mathrm{I} \cdot 64 \times \mathrm{IO}^{9}$ to $\mathrm{I} \cdot 8 \mathrm{I} \times 1 \mathrm{I}^{9}$ daltons. The taxonomic implications of these findings are discussed.
\end{abstract}

\section{INTRODUCTION}

The genetic relatedness of bacteria can be estimated from the extent of DNA reassociation. The degree of base sequence divergence within related DNAs can then be calculated from the thermal stability of the DNA-DNA duplexes formed. We have used these approaches to investigate the genetic "relatedness of flavobacteria difficult to classify by conventional bacteriological methods (Hendrie, Mitchell \& Shewan, 1968).

Flavobacterium meningosepticum, a species that is occasionally pathogenic for man (e.g. Lapage \& Owen, 1973), is similar in phenotypic characteristics and in DNA base compositions to strains of King's group II-b (Owen \& Lapage, 1974), and to Weaver's unclassified group II-f (Owen \& Snell, I973). Although F. meningosepticum is a biochemically homogeneous species (King, I959), Sottile, Baldwin \& Weaver (I973) have shown by DNA-DNA reassociation studies that strains are genotypically heterogeneous. However, although $F$. meningosepticum has six serotypes (A to F), these workers did not find any correlation between serotype and the extent of DNA relatedness.

We now report the results of DNA-DNA reassociation studies on further strains of $F$. meningosepticum, and on other miscellaneous flavobacteria with DNA base compositions in the range 32 to $46 \%$ guanine plus cytosine ( $\% \mathrm{GC}$ ). Several described species and some strains of uncertain taxonomic position have \% GC values in this range (De Ley \& Van Muylem, I963; Mitchell, Hendrie \& Shewan, 1969; Ferrari \& Cavazzoni, I972; McMeekin, Stewart \& Murray, I972; Weeks, 1974). Moraxella saccharolytica (Flamm, 1956) was 
also studied because Henriksen ( I973) considered that this organism should be classified as $F$. meningosepticum.

The DNA-DNA duplexes were thermally denatured to assess the extent of base-pair imperfections within the renatured molecules, and the genome sizes of certain strains determined.

\section{METHODS}

Organisms and cultivation. The twenty-six strains used are listed in Table I. Flavobacterium aquatile $\mathrm{NCIB} 8694$ was incubated without aeration for 5 days at $22{ }^{\circ} \mathrm{C}$ in $200 \mathrm{ml}$ of a medium containing (per litre distilled water): $2 \mathrm{~g}$ tryptone (Difco);0.5 g yeast extract (Difco); $0.5 \mathrm{~g} \mathrm{~K}_{2} \mathrm{HPO}_{4} ; 5 \mathrm{ml}$ of $50 \%$ (w/v) glucose (sterilized separately). The other strains were grown on $150 \mathrm{ml}$ nutrient agar in Roux bottles or in $200 \mathrm{ml}$ nutrient broth No. 2 medium (Oxoid) with aeration in an orbital incubator (Gallenkamp), and were cultured overnight at $37^{\circ} \mathrm{C}$, except for $F$. heparinum NCIB9290 and F. pectinovorum NCIB9059 which were grown at $30^{\circ} \mathrm{C}$.

To incorporate the radioactive label in their DNA, three strains ( $F$. meningosepticum NCTCI00I6 and NCTCI0585, and Flavobacterium group II-b NCTCI0795) were grown in a medium containing: $10 \mathrm{ml} \mathrm{M9}$ salts solution (prepared at tenfold concentration: $\mathrm{Na}_{2} \mathrm{HPO}_{4}$ $60 \mathrm{~g} ; \mathrm{KH}_{2} \mathrm{PO}_{4}, 30 \mathrm{~g} ; \mathrm{NaCl}, 5 \mathrm{~g} ; \mathrm{NH}_{4} \mathrm{Cl}$, Io g; distilled water, I l); I ml o. I M- $\mathrm{MgSO}_{4}$; I $\mathrm{ml} 0.0 \mathrm{I} \mathrm{M}-\mathrm{CaCl}_{2} ; \mathrm{I} \mathrm{g}$ tryptone (Difco); $2.5 \mathrm{ml} 40 \%(\mathrm{w} / \mathrm{v})$ maltose and $200 \mu \mathrm{g}$ thiamine (both sterilized separately); $85 \mathrm{ml}$ distilled water. The strains were grown overnight at $37{ }^{\circ} \mathrm{C}$ in $5 \mathrm{ml}$ medium, subcultured into $10 \mathrm{ml}$ of fresh medium, and then incubated at $37{ }^{\circ} \mathrm{C}$ with aeration. Deoxyadenosine $(2.5 \mathrm{mg})$ and $\left[{ }^{3} \mathrm{H}\right]$ methyl thymidine $(50 \mu \mathrm{Ci}$; The Radiochemical Centre, Amersham, Buckinghamshire) of specific activity $215 \mathrm{mCi} / \mathrm{mg}$ were added early in the exponential phase of growth, and again after $30 \mathrm{~min}$ and $\mathrm{I} \mathrm{h}$.

DNA extraction and purification. The bacteria were harvested, washed and suspended in $0 . \mathrm{I} 5 \mathrm{M}-\mathrm{NaCl}$ and $0 . \mathrm{I} \mathrm{M}$-EDTA buffer $\mathrm{pH} 8.0$ ( $5 \mathrm{~g}$ wet weight in $50 \mathrm{ml}$ buffer), and lysed at $60{ }^{\circ} \mathrm{C}$ with sodium dodecyl sulphate (SDS) at a final concentration of $2 \%(\mathrm{w} / \mathrm{v})$. The DNA was extracted and purified by the method of Marmur (I96I), supplemented by treatment with $50 \mu \mathrm{g}$ self-digested pronase (Koch-Light)/ $\mathrm{ml}$ for $\mathrm{I} \mathrm{h}$ at $37^{\circ} \mathrm{C}$, and with phenol (Brenner et al., 1969). The DNA from $M$. saccharolytica NCTC10753 was purified by gel permeation chromatography on a Sepharose 4B column equilibrated with buffered $2 \mathrm{M}-\mathrm{NaCl}$ (Zadrazil, Satava \& Sormova, 1973), because repeated attempts to obtain fibrous DNA precipitates by the Marmur procedure with this strain were unsuccessful.

The DNA samples were finally precipitated twice with $95 \%(\mathrm{v} / \mathrm{v})$ ethanol, then with either iso-propanol or 2-ethoxyethanol. Samples were dissolved in $0.0 \mathrm{I} \times \mathrm{SSC}$ (standard saline citrate: $0.15 \mathrm{M}-\mathrm{NaCl}$ and $0.015 \mathrm{M}$-sodium citrate) and stored at $4{ }^{\circ} \mathrm{C}$ over chloroform. Before use, the DNA was reprecipitated with $95 \%(\mathrm{v} / \mathrm{v})$ ethanol and dissolved in $0.06 \mathrm{M}-$ sodium phosphate buffer (equal molar concentrations of $\mathrm{Na}_{2} \mathrm{HPO}_{4}$ and $\mathrm{NaH}_{2} \mathrm{PO}_{4}$ ) at a concentration of 300 to $350 \mu \mathrm{g} / \mathrm{ml}$. The DNA purity was assessed from the $280: 260 \mathrm{~nm}$ extinction ratio (Marmur, 196I).

In the preparation of ${ }^{3} \mathrm{H}$-labelled DNA, cultures in the late-exponential phase of growth were harvested by centrifuging, washed with $0.15 \mathrm{M}-\mathrm{NaCl}$ and $0 . \mathrm{I} \mathrm{M}-\mathrm{EDTA}$ buffer at $\mathrm{pH} 8.0$, and lysed with SDS at a final concentration of $0.1 \%(\mathrm{w} / \mathrm{v})$. The suspensions were heated at $60{ }^{\circ} \mathrm{C}$ for 2 to $3 \mathrm{~min}$ to assist lysis, and the lysates sonicated (MSE ultrasonic disintegrator, $100 \mathrm{~W}$ model) for $30 \mathrm{~s}$ at $22{ }^{\circ} \mathrm{C}$ to reduce their viscosity. The DNA was purified by $\mathrm{CsCl}$ density gradient centrifugation at $90000 \mathrm{~g}\left(\mathrm{I} 8^{\circ} \mathrm{C}, 60 \mathrm{~h}\right)$ in a fixed angle rotor in a MSE Superspeed 65 centrifuge. At the end of the run each tube was pierced and eight drop fractions 
Table I. Bacterial strains used and their DNA base compositions

Species and strain designations*

NCTCI00I 6 Flavobacterium meningosepticum serotype A (ATCCI3253; strain I4) NCTC10585 F. meningosepticum serotype B (ATCC13254; strain 422)

NCTC10586 F. meningosepticum serotype C (ATCCI 3255; strain 3375)

NCTCI0587 F. meningosepticum serotype D (strain 6925)

NCTC10588 F. meningosepticum serotype E (strain 8388)

NCTCI0589 F. meningosepticum serotype F (strain 8707)

FI $23 \quad F$. meningosepticum serotype A

FI34 F. meningosepticum serotype B

NCTCI0795 Flavobacterium group II-b

NCTCI0796 Flavobacterium group II-b

NCTC 10797 Flavobacterium group II-b

F48 Flavobacterium group II-b

F93 Flavobacterium group II-b

FIOI Flavobacterium group II-b

FI29 Flavobacterium group II-b

Fi3 I Flavobacterium group II-b

FI39 Flavobacterium group II-b

NCTC10798 Unnamed group II-f

NCTC10799 Unnamed group II-f

NCTCI0800 Unnamed group II-f

NCIB8694 F. aquatile

NCIB9059 F. pectinovorum

NCIB9290 $F$. heparinum

ATCCI $4234 F$. breve

ATCC465I $F$. odoratum

NCTCI0753 Moraxella saccharolytica

NCTC10537 Escherichia coli B (DNA control strain)
Base composition $\dagger$

(\% GC)

$37 \cdot 6(\mathrm{I}), 38 \cdot 3(2), 35 \cdot 5(3)$

$36 \cdot 8(1), 36 \cdot 4(2), 50 \cdot 0(3)$

$37 \cdot 2(1), 36 \cdot 4(2), 37 \cdot 5(3)$

$36 \cdot 8(1), 38 \cdot 0(3)$

$36 \cdot 1(1), 39 \cdot 0(3)$

$37 \cdot 0(1), 31 \cdot 6(3)$

$37 \cdot 4(4)$

$37 \cdot 4(4)$

$38 \cdot 5$ ( I )

$39 \cdot 4$

$36 \cdot 1$

$36 \cdot 2$ (I)

$37 \cdot 0(1)$

$37 \cdot 9$ (I)

$36 \cdot 0(\mathrm{I})$

$38 \cdot 9$

$38 \cdot 8$

$37 \cdot 8$ (5)

$37 \cdot 2(5)$

$37 \cdot 2$ (5)

$32 \cdot 0(6)$

$34 \cdot 9,34 \cdot 2(7)$

$44 \cdot 7,45 \cdot 6(7)$

$33 \cdot 7,26.0(6)$

$36 \cdot 7$

$38 \cdot 3$ (8)

$5 \mathrm{I} \cdot 5$

* Abbreviations: NCTC, National Collection of Type Cultures, London; NCIB, National Collection of Industrial Bacteria, Aberdeen; ATCC, American Type Culture Collection, Rockville, U.S.A.; F, laboratory designation of field isolate.

$\dagger$ For values cited in the literature, references are given in parentheses: (I) Owen \& Lapage (I974); (2) Mitchell, Hendrie \& Shewan (1969); (3) Sottile, Baldwin \& Weaver (1973); (4) Lapage \& Owen (I973); (5) Owen \& Snell (1973); (6) Weeks (I974); (7) Perry (1973); (8) Snell, Hill \& Lapage (1972).

were collected. The fractions that contained DNA, identified by the ${ }^{3} \mathrm{H}-$ label, were pooled and dialysed for $\mathrm{I} \mathrm{h}$ at $4{ }^{\circ} \mathrm{C}$ against distilled water, then overnight at $4{ }^{\circ} \mathrm{C}$ against $0 \cdot 14 \mathrm{M}$ sodium phosphate buffer.

Shearing of DNA and molecular weight estimation. The solutions of DNA, at a concentration of 300 to $400 \mu \mathrm{g} / \mathrm{ml}$ in $0.06 \mathrm{M}$-sodium phosphate buffer, were sonicated (MSE ultrasonic disintegrator) in $3 \mathrm{ml}$ volumes for two periods of $\mathrm{I}$ min at room temperature. Molecular weights of sheared DNA were determined from band sedimentation through $\mathrm{I} \mathrm{M}-\mathrm{NaCl}$ and $0.05 \mathrm{M}-\mathrm{Na}_{2} \mathrm{HPO}_{4}, \mathrm{pH} 7$, in a MSE Centriscan analytical ultracentrifuge. The sedimentation coefficients were measured at $60000 \mathrm{~g}$ and $20^{\circ} \mathrm{C}$, corrected to $s_{20, \mathrm{w}}^{\circ}$ at $\mathrm{pH} 7$, and the molecular weights calculated according to Studier (1965).

$D N A$ reassociation. About 150 to $200 \mu \mathrm{g}$ of unlabelled, sheared DNA in $0.06 \mathrm{M}$-sodium phosphate buffer were mixed with $0.05 \mu \mathrm{g}$ of sheared ${ }^{3} \mathrm{H}$-labelled DNA. The ratio of the concentrations of unlabelled to labelled DNA was approximately $3000: \mathrm{I}$. The DNA mixture was denatured at 95 to $100{ }^{\circ} \mathrm{C}$ for 15 min and the buffer concentration adjusted to $0.28 \mathrm{M}$ with $0.5 \mathrm{M}$-sodium phosphate buffer. The reassociation reaction was allowed to proceed to I $00 c_{0} t$ for the unlabelled DNA in a $20 \mathrm{~h}$ period of incubation, where $c_{0} t$ is the acronym for the product of the initial DNA concentration $\left(c_{0}\right)$ and the incubation time $(t)$ (Britten \& 
Kohne, 1966). Chemical units are mol s/l. The incubation temperatures selected are described in Results. The methods described below refer to an incubation temperature of $65^{\circ} \mathrm{C}$.

Duplex fractionation and binding assay. The hydroxyapatite (HA) procedure of Brenner et al. (1969) was used to fractionate the unbound single stranded DNA fragments from the reassociated DNA duplexes. Eight samples were run simultaneously. The DNA mixtures were adjusted to $0.14 \mathrm{M}$-sodium phosphate buffer and each was added to $10 \mathrm{ml}$ suspension of hydroxyapatite (Bio-Gel HT; Bio-Rad Laboratories), mixed well, and equilibrated at $65^{\circ} \mathrm{C}$ for $10 \mathrm{~min}$. The volume was increased to $20 \mathrm{ml}$ and the mixture again thoroughly mixed. The samples were centrifuged at 60 to $65^{\circ} \mathrm{C}$ and the aqueous supernatants collected. The samples were then washed twice with $20 \mathrm{ml}$ portions of $0.14 \mathrm{M}$-sodium phosphate buffer at $65{ }^{\circ} \mathrm{C}$ to remove all the unbound single strand DNA. The three supernatants from each sample were pooled.

Samples not required for thermal analysis were washed three times with $20 \mathrm{ml}$ portions of $0.4 \mathrm{M}$-sodium phosphate buffer at $65^{\circ} \mathrm{C}$ to elute the double stranded DNA from the HA. The supernatants were collected by centrifuging and pooled.

Yeast RNA $(200 \mu \mathrm{g})$ was added as carrier to each of the pooled supernatants, and the DNA precipitated with $5 \%(\mathrm{w} / \mathrm{v})$ trichloracetic acid (TCA) at $4{ }^{\circ} \mathrm{C}$. The nucleic acid precipitates were collected by suction filtration on Whatman GF/B discs $(2.5 \mathrm{~cm}$ diameter $)$ and washed with $2.5 \%(\mathrm{w} / \mathrm{v})$ TCA followed by $95 \%(\mathrm{v} / \mathrm{v})$ ethanol. The discs were dried for $30 \mathrm{~min}$ in an hot air oven and suspended in $5 \mathrm{ml}$ scintillation fluid, containing: 2,5-diphenyloxazole, $4 \mathrm{~g}$; I ,4 bis-[2-(4 methyl-5-phenyloxazolyl)]-benzene, $0.5 \mathrm{~g}$; toluene, $1 \mathrm{l}$. They were then counted repeatedly in a Packard Tri-Carb model 2002 liquid scintillation spectrometer.

The observed homologous binding for each $\left[{ }^{3} \mathrm{H}\right]$ DNA was arbitrarily designated $100 \%$ and the reassociation values of the heterologous DNA reactions were determined relative to the binding values of the homologous DNA.

Thermal stability of duplexes. The DNA duplexes bound to the HA, after removal of the single strand DNA fragments in 0.14 M-sodium phosphate buffer, were analysed by thermal denaturation. Samples were washed with $20 \mathrm{ml}$ volumes of 0.14 M-sodium phosphate buffer at temperature increments of $5{ }^{\circ} \mathrm{C}$ over the range 65 to $95{ }^{\circ} \mathrm{C}$ in a water bath, being equilibrated at each temperature for $10 \mathrm{~min}$ with mixing at $5 \mathrm{~min}$ intervals. The supernatants were collected by centrifuging at $65^{\circ} \mathrm{C}$ to prevent reassociation of the denatured DNA fragments and possible non-specific binding to the HA. The samples were finally washed with $20 \mathrm{ml} \mathrm{0.4} \mathrm{M}$-sodium phosphate buffer and boiled to remove any DNA duplexes that had not denatured. The DNA in each sample was precipitated with $5 \%(\mathrm{w} / \mathrm{v})$ TCA and the radioactivity measured as before. The duplex melting temperature $\left(T_{m(e)}\right)$ was calculated as the temperature at which $50 \%$ of the DNA fragments had dissociated and eluted from the HA. The temperature range of melting $(\Delta T)$ and the ranges of melting on the right (high temperature) side $\left(\Delta T_{r}\right)$ and on the left (low temperature) side $\left(\Delta T_{l}\right)$ of the duplex melting temperature were calculated according to De Ley (1969). The ratio $\left(\Delta T_{r}: \Delta T_{l}\right)$ is a measure of the symmetry of the duplex melting profile.

Optimum renaturation temperature. The optimum renaturation temperature $\left(T_{o r}\right)$ was calculated from the equation of Gillis, De Ley \& De Cleene (1970):

$$
T_{\text {or }}=0.5 \mathrm{I} \times \% \mathrm{GC}+47.0 .
$$

Estimation of base composition. The mean base composition of the DNA was estimated from its melting temperature $\left(T_{m}\right)$, which was determined by the method of Marmur \& Doty (1962). Thermal denaturation (melting) was carried out in a Pye Unicam SP I 800 
spectrophotometer equipped with a SP 876 series 2 temperature programme controller and heated cell block. The extinction changes at $260 \mathrm{~nm}$ were recorded on a Pye Unicam AR 25 linear recorder. The temperature of the DNA solution was measured with a thermistor thermometer as described by Hill (1968). The DNA mean base composition, expressed as percentage guanine and cytosine to total bases ( $\% \mathrm{GC})$, was calculated from the $T_{m}$ determined in SSC buffer using Marmur \& Doty's ( 1962) equation:

$$
\% \mathrm{GC}=2 \cdot 44 T_{m}-\mathrm{I} 69 \cdot 0 .
$$

Spectrophotometric determination of genome size. The genome size (molecular complexity) of the DNA was estimated by the renaturation rate method of Gillis et al. (1970). Sonicated, denatured DNA at a concentration of $35 \mu \mathrm{g} / \mathrm{ml}$ in $2 \times \mathrm{SSC}$ buffer was renatured in a spectrophotometer (see above) for periods of $40 \mathrm{~min}$ at the temperature of optimum renaturation. Three separate determinations were made on each strain. The apparent renaturation rate constant $\left(k^{\prime}\right)$ was calculated from the equation $k^{\prime}=v / c^{2}$, where $v$ is the initial renaturation rate expressed as decrease in extinction at $260 \mathrm{~nm} / \mathrm{min}$, and $c$ represents the DNA concentration expressed as mmol nucleotide pairs/l. The concentrations of the DNA samples were assayed by the chemical method of Burton (1956) with 2-deoxy-D-ribose as the standard.

The renaturation rate constant is inversely proportional to molecular complexity (Britten \& Kohne, 1966), so genome sizes were calculated relative to a reference DNA (Escherichia coli $\mathrm{B})$ with an average molecular weight, obtained from chemical determinations, of $2.88 \times 10^{9}$ daltons (Gillis et al., 1970).

\section{RESULTS}

\section{Yields of labelled DNA}

The radioactive label $\left(\left[{ }^{3} \mathrm{H}\right]\right.$ methyl thymidine) was incorporated in the DNA of the three reference strains (NCTCIOOI6, NCTCI0585 and NCTCI0795). The use of preparative ultracentrifugation in the isolation and purification of the labelled DNA proved to be economical in both time and the amount of label used. Each $\mathrm{I} 0 \mathrm{ml}$ of lysate yielded approximately $30 \mu \mathrm{g}$ of highly pure labelled DNA, with a specific activity of $1 \cdot 5 \times 10^{4}$ to $7 \cdot 0 \times 10^{4}$ counts $/ \mathrm{min} / \mu \mathrm{g}$.

\section{Size of DNA fragments}

The sonication procedure yielded DNA fragments estimated from band sedimentation to have molecular weights of $2 \times 10^{5}$ to $3 \times 10^{5}$ daltons. These results are in agreement with the values for sonically-fragmented DNA estimated from electron microscopy by Grindley, Humphreys \& Anderson (1973).

\section{Effect of temperature on reassociation of homologous DNA}

Kinetic studies on DNA reassociation have shown that the specificity of base pairing and the extent of renaturation of homologous DNA depend primarily on the incubation temperature, when other factors such as DNA concentration, salt concentration of buffer, incubation time and fragment size do not limit the reaction (Britten \& Kohne, I966; Wetmur \& Davidson, 1968; De Ley et al., 1973). There is no direct method to calculate the most suitable temperature at which to estimate DNA relatedness, so the effect of temperature on the percentage binding of a homologous DNA system was first determined. The $\left[{ }^{3} \mathrm{H}\right] \mathrm{DNA}$ of NCTCIOOI 6 was reassociated with homologous unlabelled DNA fragments at the following renaturation temperatures; $55,60,65,70$ and $75{ }^{\circ} \mathrm{C}$. The binding values ranged from 89 to $94 \%$ and were therefore almost independent of temperature over the range selected. The 


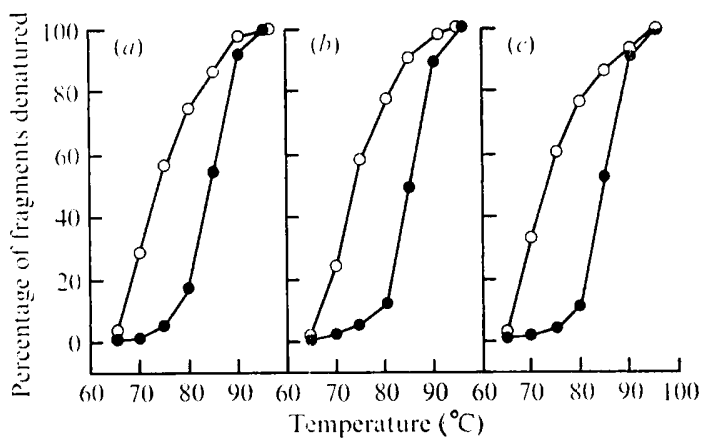

Fig. I. Thermal denaturation curves of DNA-DNA duplexes. The sheared denatured $\left[{ }^{3} \mathrm{H}\right] \mathrm{DNA}$ $(0.05 \mu \mathrm{g})$ was reassociated with excess unlabelled, denatured DNA fragments ( 150 to $200 \mu \mathrm{g}$ ) in $0.28 \mathrm{M}$-sodium phosphate buffer at $65^{\circ} \mathrm{C}$ for $20 \mathrm{~h}$. The duplexes were fractionated from unreassociated DNA and thermally denatured in $0.14 \mathrm{M}$-sodium phosphate buffer as described in the text. (a) Duplexes of $F$. meningosepticum NCTCI00I $6\left[{ }^{3} \mathrm{H}\right] \mathrm{DNA}$ with: () unlabelled NCTC 10016 DNA and $(O)$ unlabelled DNA from $F$. meningosepticum NCTC10585. (b) Duplexes of $F$. meningosepticum NCTC $10585\left[{ }^{3} \mathrm{H}\right]$ DNA with : (O) unlabelled NCTC10585 DNA and $(O)$ unlabelled NCTC 10016 DNA. (c) Duplexes of Flavobacterium group II-b NCTC10795 $\left[{ }^{3} \mathrm{H}\right] \mathrm{DNA}$ with: () unlabelled NCTC10795 DNA and (O) unlabelled DNA from Flavobacterium group II-b FIOI.

renaturation temperature of $65{ }^{\circ} \mathrm{C}$ used in all further reassociations, corresponded to the predicted temperature of optimum renaturation for a DNA of $35.3 \% \mathrm{GC}$ in a buffer of approximately $0.4 \mathrm{M}$-sodium ion concentration. The effect of lowering the renaturation temperature to $55^{\circ} \mathrm{C}$ was investigated for some strains that had low binding values at $65{ }^{\circ} \mathrm{C}$, to determine if less stringent conditions would permit reassociation of more distantly related nucleotide sequences.

\section{Reassociation and duplex characteristics of reference DNAS}

The average percentage reassociations at $65{ }^{\circ} \mathrm{C}$ for the three reference [ $\left.{ }^{3} \mathrm{H}\right] \mathrm{DNAs}$ in homologous systems were: 9I \% for NCTCl00I6, $97 \%$ for NCTCI0585 and $94 \%$ for NCTCI0795. The homoduplexes of these three DNAs had sharp, sigmoid-shaped melting profiles (Fig. 1 ) and thermal stability ranges which were similar to those of the high molecular weight native DNA obtained from the same strains (Owen \& Lapage, 1974). The homoduplexes of NCTCIOOI 6 formed at 55 and $65^{\circ} \mathrm{C}$ had identical melting profile characteristics, with less than $5 \%$ of the reassociated molecules consisting of fragments with low thermal stability. In the absence of excess unlabelled DNA, reassociation of each of the three labelled DNAs with itself was $5 \%$ or lower.

\section{Reassociation between $\left[{ }^{3} H\right] D N A$ and $F$. meningosepticum strains}

Table 2 lists the percentage relative binding and duplex characteristics of reassociations between the three reference $\left[{ }^{3} \mathrm{H}\right] \mathrm{DNAs}$ and DNA from the eight strains of $F$. meningosepticum. Labelled DNA from NCTC10585 bound at high levels (9I to $95 \%$ ) with DNA from all the $F$. meningosepticum strains except NCTCIO0I 6 , to which it was only $43 \%$ reassociated. The heteroduplexes of the six strains that reassociated to $90 \%$ or more had melting profiles in the same temperature range as the NCTC10585 homoduplex (Fig. I $b$ ). Well matched base sequences in the reassociated molecules were indicated by high thermal stabilities with $\Delta T_{m(e)}$ values of $2{ }^{\circ} \mathrm{C}$ or lower $\left(\Delta T_{m(e)}\right.$ designates the difference between the $T_{m(e)}$ of the homoduplex and that of the heteroduplex), by the narrow temperature ranges of melting, and by the symmetrical shapes of the profiles, which were similar to those of the homoduplex 
DNA reassociation of flavobacteria

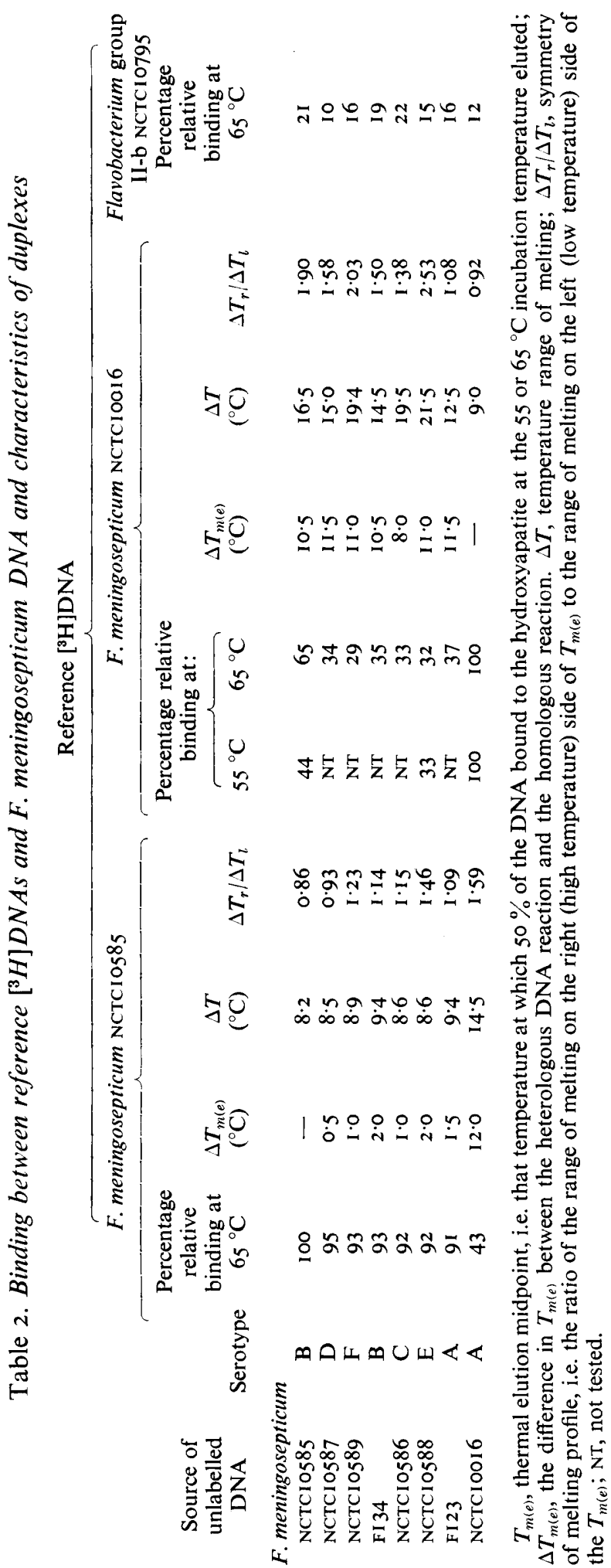

M IC 93 
profiles. In contrast, the NCTCIOOI6: NCTCI0585 ${ }^{3} \mathrm{H}$-heteroduplex molecules contained renatured regions with a higher degree of base mismatching, as shown by the parabolic shape of the melting curve (Fig. $\mathrm{I} b$ ), the decreased thermal stability, the broader range of melting, and the asymmetrically shaped profile. In the reciprocal reaction between NCTCIO0I6 $\left[{ }^{3} \mathrm{H}\right] \mathrm{DNA}$ and unlabelled DNA of NCTCI0585, the mean binding was $65 \%$ at $65{ }^{\circ} \mathrm{C}$ and $44 \%$ at $55^{\circ} \mathrm{C}$. The characteristics of the heteroduplexes formed at these two temperatures were unchanged, except that the melting temperature of the duplex formed at $55^{\circ} \mathrm{C}$ was approximately $\mathrm{I}{ }^{\circ} \mathrm{C}$ lower. The reproducibility of binding between NCTCIO0I6 and NCTCI0585 was poor ( $\pm 15 \%$ ) compared with the values of $\pm 5 \%$ for reactions between most other DNAs. A reason for less reproducibility could be that partially-related DNA fragments renature to varying degrees if the reassociation reaction on repetition is initiated at different positions along the fragments, with the formation of different amounts of free ends and open loops in the duplex molecules.

The relative binding between NCTCI006 [ $\left.{ }^{3} \mathrm{H}\right]$ DNA and DNA of the six other $F$. meningosepticum strains ranged between 29 and $37 \%$ (Table 2). The $\Delta T_{m(e)}$ values of 8 to II $\cdot 5{ }^{\circ} \mathrm{C}$ and the other melting profile characteristics indicated significant levels of base mismatching within the heteroduplex molecules.

The labelled DNA from NCTCI0795 Flavobacterium group II-b was bound only at low levels (Io to $22 \%$ ) with DNA of the eight $F$. meningosepticum strains (Table 2).

The number of DNA fragments denatured at each $5{ }^{\circ} \mathrm{C}$ increment during the thermal analysis of $F$. meningosepticum duplexes is illustrated in Fig. 2. In three heteroduplexes ([ $\left.{ }^{3} \mathrm{H}\right]$ DNA of NCTCIOOI6:NCTCI0585, of NCTCIOOI6:NCTCI0587 and of NCTCI0585: NCTCI00I6) most of the label was bound in a labile, easily-denatured form. The characteristics of these duplexes suggested they probably consisted of relatively unspecific base paired regions, interspersed within regions of well matched bases.

\section{Reassociation between $\left[{ }^{3} H\right] D N A$ and Flavobacterium group II-b strains}

[ $\left.{ }^{3} \mathrm{H}\right]$ DNA of NCTC10795, the selected reference strain of Flavobacterium group II-b, reassociated to a high level and formed stable duplexes with two other strains (F93 and FI29) of group II-b but only reassociated at values ranging from 7 to $47 \%$ with the other six strains of the group (Table 3). The heteroduplexes of the latter had lower melting temperatures and broader melting profiles (Fig. I $c$ ) than the NCTCI0795 homoduplex. The heteroduplexes with strains FI3I and FI39 (47\% reassociated) contained a higher proportion of label bound in the form of stable duplexes than did FIOI and NCTCIO796 $(30 \%$ reassociated), which had most of the label bound in a labile form (Fig. 3).

The levels of binding at $65{ }^{\circ} \mathrm{C}$ were low between the $\left[{ }^{3} \mathrm{H}\right] \mathrm{DNA}$ of the two $F$. meningosepticum reference strains and the eight Flavobacterium group II-b strains (Table 3). For the reaction between NCTCI0795 and NCTCI00I6 [ ${ }^{3} \mathrm{H}$ ]DNA, a less stringent renaturation temperature $\left(55^{\circ} \mathrm{C}\right)$ resulted in $17 \%$ more binding. Thermal analysis of the DNA duplexes revealed that the increase in binding was due to the formation of labile molecules with thermal stabilities below $65^{\circ} \mathrm{C}$.

\section{Reassociation of $\left[{ }^{3} \mathrm{H}\right] D N A$ and miscellaneous flavobacteria}

The three reference $\left[{ }^{3} \mathrm{H}\right.$ ]DNAs had binding levels of $28 \%$ or less at $65{ }^{\circ} \mathrm{C}$ with the strains of group II-f, F. aquatile, $F$. heparinum, F. pectinovorum, F. breve, F. odoratum and Moraxella saccharolytica (Table 4 ). The duplexes between these strains were not investigated further, as the amount of label bound was low and it was difficult to obtain reproducible melting profiles. The group II-f strain NCTCI0799, F. heparinum and $F$. odoratum were also 


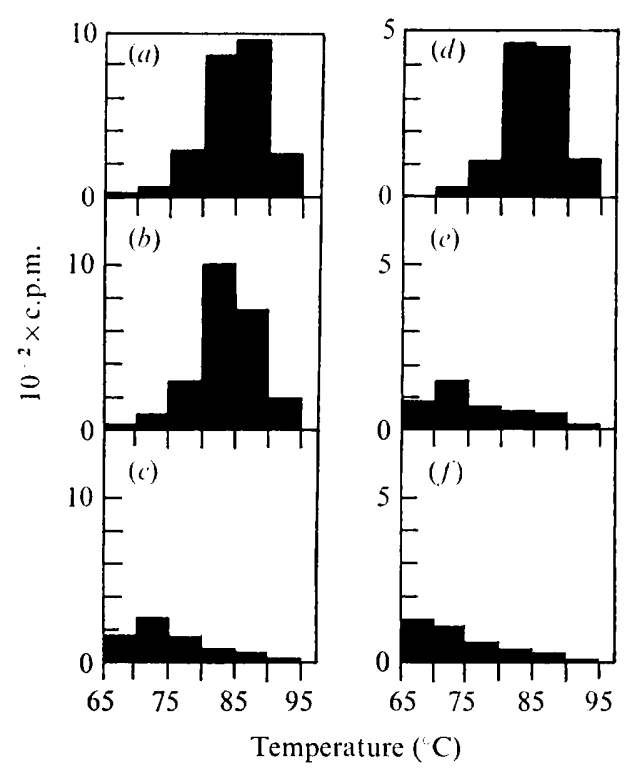

Fig. 2

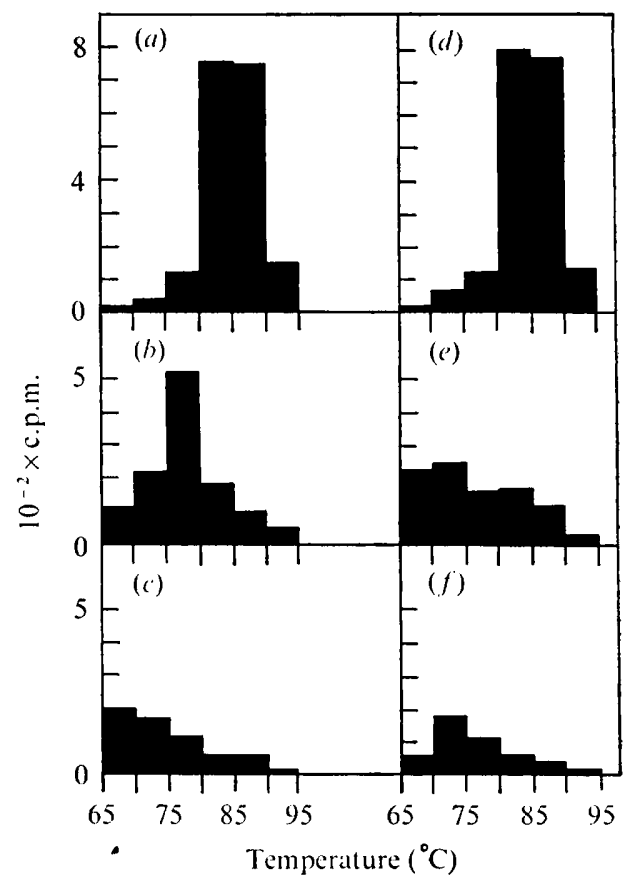

Fig. 3

Fig. 2. Differential denaturation profiles of $F$. meningosepticum DNA-DNA duplexes. For methods see Fig. I. Duplexes of $F$. meningosepticum NCTCI0585 $\left[{ }^{3} \mathrm{H}\right] \mathrm{DNA}$ and unlabelled DNA from: (a) NCTCI0585 (homoduplex), (b) F. meningosepticum FI23, and (c) F. meningosepticum NCTCIOOI6. Duplexes of $F$. meningosepticum NCTCI0016 [ ${ }^{3} \mathrm{H}$ ]DNA and unlabelled DNA from: $(d)$ NCTC10016 (homoduplex), (e) F. meningosepticum NCTCI0585, and $(f) F$. meningosepticum NCTCI0587.

Fig. 3. Differential denaturation profiles of the DNA-DNA duplexes of strains of Flavobacterium group II-b. For methods see Figs. I. The labelled DNA in each duplex was from NCTCI0795. The unlabelled DNA was from: (a) NCTC 10795 (homoduplex), (b) FI 3I, (c) FIOI, (d) FI 29, (e) FI 39, and $(f)$ NCTCI0796.

reassociated with NCTCIOOI $6\left[{ }^{3} \mathrm{H}\right] \mathrm{DNA}$ at $55^{\circ} \mathrm{C}$, but the levels of binding obtained at this less stringent reassociation temperature were not significantly different from the $65{ }^{\circ} \mathrm{C}$ values.

\section{Bacterial genome sizes}

Genome size estimations are summarized in Table 5. The renaturation rates were not corrected for the \% GC content of the DNA as described by Gillis et al. (1970), as other evidence for this effect is contradictory (Wetmur \& Davidson, 1968). Christiansen, Christiansen \& Bak (1973) found that the renaturation rate of $\mathrm{T}_{4}$ phage DNA was influenced by the degree of glucosylation of the bases rather than by $\%$ GC content, and they concluded that a correction for the latter was unnecessary.

The three strains of $F$. meningosepticum (NCTCI00I6, NCTCI0585 and NCTCI0589) and the three strains of Flavobacterium group II-b (NCTCI0795, F48 and F139) had genome sizes between $2.50 \times 10^{9}$ and $3.52 \times 10^{9}$ daltons. The close agreement between the values of the reciprocal binding reactions of NCTCI00I6, NCTCI0585 and NCTCI0795 provided further evidence that these strains had approximately the same molecular complexity. The genome sizes of the group II-f strains (NCTCI0799 and NCTCI0800) of $\mathrm{I} \cdot 64 \times 10^{9}$ to $\mathrm{I} \cdot 8 \mathrm{I} \times 1 \mathrm{IO}^{9}$ daltons, were approximately $40 \%$ smaller than the values of the flavobacteria strains. 


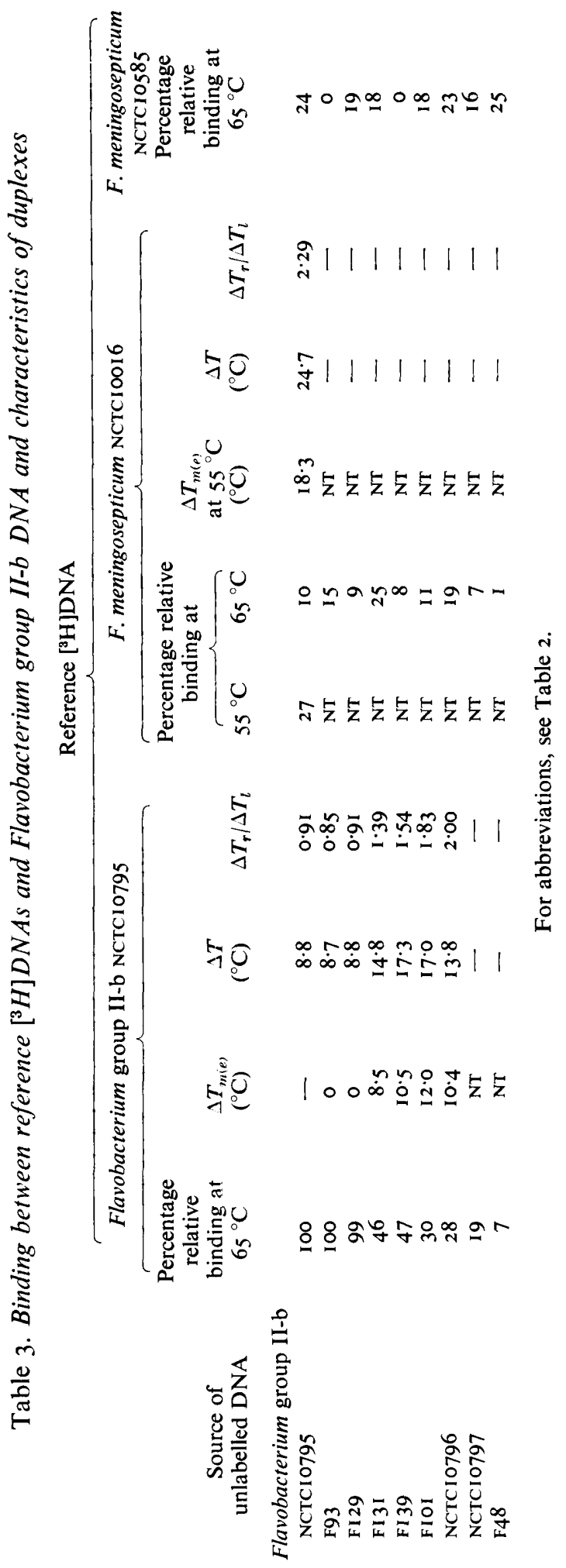


Table 4. Binding between reference $\left[{ }^{3} \mathrm{H}\right] \mathrm{DNAs}$ and miscellaneous flavobacteria

\begin{tabular}{|c|c|c|c|c|}
\hline \multirow[b]{3}{*}{ Source of unlabelled DNA } & \multicolumn{4}{|c|}{ Relative binding of reference $\left[{ }^{3} \mathrm{H}\right] \mathrm{DNA}(\%)$} \\
\hline & \multicolumn{2}{|c|}{$\begin{array}{c}F . \text { meningosepticum } \\
\text { NCTCI0016 at }\end{array}$} & \multirow{2}{*}{$\begin{array}{c}F . \text { meningosepticum } \\
\text { NCTCIO585 } \\
\text { at } 65{ }^{\circ} \mathrm{C}\end{array}$} & \multirow{2}{*}{$\begin{array}{l}\text { Flavobacterium } \\
\text { group II-b } \\
\text { NCTCI0795 } \\
\text { at } 65^{\circ} \mathrm{C}\end{array}$} \\
\hline & $65^{\circ} \mathrm{C}$ & $55^{\circ} \mathrm{C}$ & & \\
\hline NCTC 10798 II-f group & 17 & NT & 4 & 6 \\
\hline NCTC10799 II-f group & 6 & 7 & 7 & I 8 \\
\hline NCTC I 0800 II-f group & 16 & NT & $2 \mathrm{I}$ & 25 \\
\hline NCIB8694 F. aquatile & 3 & NT & 0 & 12 \\
\hline ATCCI4234 $F$. breve & 7 & NT & 0 & 2 \\
\hline NCIB9290 $F$. heparinum & 25 & 20 & 28 & 18 \\
\hline NCIB9059 $F$. pectinovorum & 14 & NT & 4 & 7 \\
\hline ATCC4651 F. odoratum & 3 & 0 & 20 & 13 \\
\hline NCTC10753 $M$. saccharolytica & I I & NT & 19 & I \\
\hline
\end{tabular}

Table 5. Spectrophotometric estimates of genome sizes

\begin{tabular}{|c|c|c|c|}
\hline Strain & $\begin{array}{l}\text { Optimum } \\
\text { renaturation } \\
\text { temperature* } \\
\left({ }^{\circ} \mathrm{C}\right)\end{array}$ & $\begin{array}{l}\mathrm{IO}^{-9} \times \text { Genome size } \dagger \\
\text { and S.D. (daltons) }\end{array}$ & $\begin{array}{c}\text { Genome size } \\
\text { relative to } \\
\text { NCTCIO585 } \\
(\%)\end{array}$ \\
\hline \multicolumn{4}{|c|}{ Flavobacterium meningosepticum } \\
\hline NCTC 10585 & $65 \cdot 9$ & $2 \cdot 85 \pm 0.10(2)$ & 100 \\
\hline NCTCIOOI 6 & $65 \cdot 9$ & $2 \cdot 50 \pm 0.14(4)$ & 88 \\
\hline NCTC10589 & 65.9 & $2 \cdot 85 \pm 0.12(3)$ & 100 \\
\hline \multicolumn{4}{|c|}{ Flavobacterium group II-b } \\
\hline NCTCIO795 & $66 \cdot 6$ & $3.52 \pm 0.25(3)$ & 124 \\
\hline F48 & $65 \cdot 7$ & $3 \cdot 07 \pm 0.38(3)$ & 108 \\
\hline FI39 & $66 \cdot 8$ & $2 \cdot 85 \pm 0.06(3)$ & 100 \\
\hline \multicolumn{4}{|c|}{ Flavobacterium group II-f } \\
\hline NCTC10799 & $65 \cdot 9$ & $\mathrm{I} \cdot 8 \mathrm{I} \pm 0.08$ & 64 \\
\hline NCTCIO800 & 65.9 & $I \cdot 64 \pm 0.06(3)$ & 58 \\
\hline
\end{tabular}

* Calculated from the formula $T_{\text {or }}=0.5 \mathrm{I} \times \% \mathrm{GC}+47.0$ (Gillis et al., 1970).

$\dagger$ The genome size of a prokaryotic organism is the amount of chromosomal DNA it contains, expressed in molecular weight units (daltons). The apparent reaction rate constant $\left(k^{\prime}\right)$ was determined in $2 \times$ SSC buffer as described in the text. Genome size was calculated from the formula:

$$
\text { Genome size }=\frac{k^{\prime}(\text { E. coli } \mathrm{B}) \times 2.88 \times 10^{9}}{k^{\prime}(\text { unknown })}
$$

Numbers in parentheses are the numbers of determinations.

\section{DISCUSSION}

In previous studies (King, I959; Owen \& Lapage, 1974), F. meningosepticum formed a homogeneous species with respect to phenotypic characteristics and DNA base composition but contained strains divisible into six serological types. The close relationship among the strains used, except for NCTCIO0I6, is confirmed by the DNA-DNA reassociation results with labelled DNA from $F$.meningosepticum NCTCI0585. The seven strains previously classified as $F$. meningosepticum on biochemical and serological grounds formed a highly interrelated genotypic group. Between strains, the standard deviation of $\Delta T_{m(e)}$ was less than I $5{ }^{\circ} \mathrm{C}$. Sottile et al. (I973) also found that NCTCIOOI6 (King's strain I4) was apparently 
genetically atypical of $F$. meningosepticum. They used the DNA-agar method, with reassociations carried out in $2 \times \mathrm{SSC}$ buffer at $55^{\circ} \mathrm{C}$ (a non-exacting reassociation temperature); and, with the same strains as investigated here, obtained an average of $26 \%$ relative binding over a range of 6 to $47 \%$ binding for labelled DNA from King's strain 14. The small differences in results between laboratories can be attributed to the variations in reassociation techniques and conditions used. However, there are significant differences between the base composition values estimated for some strains (see Table 1), particularly the value of $50 \%$ GC reported by Sottile et al. (1973) for NCTC10585 (King's strain 422). This value was estimated from measurement of its buoyant density in $\mathrm{CsCl}$, whereas estimates from melting temperature were appreciably lower at 36.4 to $36.8 \% \mathrm{GC}$ (Mitchell et al., I 969 ; Owen \& Lapage, 1974). The presence of glycosylated or unusual bases, such as substituted cytosines, decreases the buoyant density of DNA in $\mathrm{CsCl}$ (Szybalski, 1968) and may also influence the reassociation rate of DNA (Christiansen et al., I 973). However, there is no evidence from our reassociation results on NCTC10585 to suggest that this strain contains a significant amount of unusual bases in its DNA.

The DNA sequences common to NCTC100I6 and the other strains of $F$. meningosepticum (except for NCTCI0585 which had $10 \%$ higher relatedness) constitute on average $33 \%$ of the genome, or $1 \cdot 3 \times 10^{6}$ base pairs, as the genome size of NCTCI00I 6 is $2.50 \times 10^{9}$ daltons. The factor used for the calculation of base sequence or evolutionary divergence from DNA-DNA duplex melting profiles is a decrease in $T_{m(e)}$ of $\mathrm{I} \cdot 6{ }^{\circ} \mathrm{C}$ per I $\cdot 0 \%$ unpaired or mismatched bases (McCarthy \& Farquhar, 1972); therefore within the reassociated regions of the NCTCIOOI 6 heteroduplexes there were approximately $6.6 \%$ or $8.6 \times 10^{4}$ mismatched base pairs. The apparent evolutionary divergence in the DNA base sequence of NCTCI00I6 is not reflected in the phenotypic data, as this strain showed no significant biochemical differences from others in the species (King, 1959). However, comparative zymograms (Snell, unpublished results) indicate that NCTCI00I6 has structural differences in several protein molecules. The catalase, malate dehydrogenase and glutamate dehydrogenase bands of NCTCIOOI 6 had marked differences in electrophoretic mobilities from those of five other F. meningosepticum strains. The results on NCTCIOC I 6 could, alternatively, be attributed to evolutionary convergence, when the high level of phenotypic similarity would be consistent with a lower level of genetic relatedness. The possibility cannot be overlooked, however, that the unexpectedly low reassociation levels of NCTCrooI 6 in heterologous $F$. meningosepticum DNA reactions is due to some structural modification of the bases, as discussed above, or to the presence of closely bound nucleoprotein, which may also reduce the rate of DNA reassociation.

Within Flavobacterium group II-b the strains show a gradation of DNA relatedness which is reffected in the heterogeneity of their biochemical characteristics (Owen \& Lapage, 1974). The high level of genetic relatedness of three strains (NCTC10795, F93 and FI29) provides evidence for at least one distinct species within group II-b. The other strains had a greater divergence in base sequence and the possibility of correlations between the level of DNA relatedness within the group and specific biochemical characteristics is currently under investigation.

In earlier studies on the unnamed group II-f (Owen \& Snell, I973), we concluded that insufficient phenotypic evidence was available to classify the strains either in Flavobacterium or in Moraxella. Even if the smaller size of the group II-f genome is taken into account, the average relatedness of this group to F. meningosepticum is still low (about 20 to $30 \%$ ). Similar genome size does not imply a taxonomic relationship, but it is of interest that the group II-f genome sizes of $\mathrm{I} \cdot 64 \times 10^{9}$ to $\mathrm{I} \cdot 8 \mathrm{I} \times 10^{9}$ daltons, correspond closely to the 
$1 \cdot 20 \times 10^{9}$ to $1 \cdot 70 \times 10^{9}$ dalton size range for species of moraxellas (Snell, unpublished results). Moraxella saccharolytica, an organism isolated from a case of meningitis in a child (Flamm, 1956), was considered by H. Lautrop (personal communication to S. D. Henriksen, 1973) to belong to $F$. meningosepticum. However, we found insufficient DNA relatedness between this organism and strains of $F$. meningosepticum to support this proposal. The problems encountered in the preparation of DNA from this strain also suggest it is different from the DNA of F. meningosepticum. Unfortunately, insufficient DNA was available for its genome size to be estimated.

We have found that DNA-DNA reassociation is a valuable technique for elucidating the relatedness of strains within a species, where high ( $70 \%$ or greater) levels of binding are to be expected (Brenner, 1973; Johnson, 1973). However, since it was difficult to assign the strains showing lower levels of reassociation to any particular taxonomic rank, no firm conclusions could be drawn about the evolutionary relatedness among the various species and strains of flavobacteria investigated. Bonner et al. (1973) found that base sequence divergence has a significant effect upon the rate of reassociation, so reaction conditions optimized for the homologous DNA may not be appropriate for the heterologous DNA reactions. In such cases, it is important that further studies be carried out to determine the experimental conditions that will ensure the reaction is essentially complete, otherwise the extent of relatedness may be under-estimated.

We thank Dr G. O. Humphreys of the Enteric Reference Laboratory for his assistance in preparing the labelled DNA and for his many useful suggestions. We also thank Dr S. P. Lapage, Curator of the National Collection of Type Cultures, for his support and advice, and the Public Health Laboratory Service which made this work possible.

\section{REFERENCES}

Bonner, T. I., Brenner, D. J., Neufeld, B. R. \& Britten, R. J. (I973). Reduction in the rate of DNA reassociation by sequence divergence. Journal of Molecular Biology 81, I 23-I 35 .

BRENNER, D. J. ( 1973). Deoxyribonucleic acid reassociation in the taxonomy of enteric bacteria. International Journal of Systematic Bacteriology 23, 298-307.

Brenner, D. J., Fanning, G. R., Rake, A. V. \& Johnson, K. E. (1969). Batch procedure for thermal elution of DNA from hydroxyapatite. Analytical Biochemistry 28, 447-459.

Britten, R. J. \& Kohne, D. E. (I966). Nucleotide sequence repetition in DNA. Yearbook of the Carnegie Institution, Washington 65, 78-106.

Burton, K. (1956). A study of the conditions and mechanism of the diphenylamine reaction for the colorimetric estimation of deoxyribonucleic acid. Biochemical Journal 62, 3I 5-323.

Christiansen, C., Christiansen, G. \& BaK, A. L. (I973). The influence of glucosylation on the renaturation rate of T4 phage DNA. Biochemical and Biophysical Research Communications 52, 1426-1433.

DE LEY, J. ( I969). Compositional nucleotide distribution and the theoretical prediction of homology in bacterial DNA. Journal of Theoretical Biology 22, 89-116.

De Ley, J., Tijtgat, R., De Smedt, J. \& Michiels, M. (1973). Thermal stability of DNA:DNA hybrids within the genus Agrobacterium. Journal of General Microbiology 78, 24I-252.

De Ley, J. \& VAN MuYlem, J. (1963). Some applications of deoxyribonucleic acid base composition in bacterial taxonomy. Antonie van Leeuwenhoek 29, 344-358.

Ferrari, A. \& Cavazzoni, V. (1972). Composizione in basi dell'acido desossiribonucleico di ceppi di flavobatteri. Annali di Microbiologia ed Enzymologia 22, 137-143.

Flamm, H. (1956). Moraxella saccharolytica (sp.n) aus dem Liquor eines Kindes mit Meningitis. Zentralblatt fïr Bakteriologie, Parasitenkunde, Infektionskrankheiten und Hygiene Abteilung (1) 168, 26I-267.

Gillis, M., De Ley, J. \& De Cleene, M. (1970). The determination of molecular weight of bacterial genome DNA from renaturation rates. European Journal of Biochemistry 12, 143-153.

Grindley, N. D. F., Humphreys, G. O. \& Anderson, E. S. (I973). Molecular studies of R factor compatibility groups. Journal of Bacteriology II5, 387-398.

Hendrie, M. S., Mitchell, T. G. \& Shewan, J. M. (1968). The identification of yellow pigmented rods. In Identification Methods for Microbiologists, B, pp. 67-78. Edited by B. M. Gibbs and D. A. Shapton. London: Academic Press. 
Henriksen, S. D. (1973). Moraxella, Acinetobacter, and the Mimeae. Bacteriological Reviews 37, 522-56I.

HiLl, L. R. (1968). The determination of deoxyribonucleic acid base compositions and its application to bacterial taxonomy. In Identification Methods for Microbiologists, B, pp. 177-186. Edited by B. M. Gibbs and D. A. Shapton. London: Academic Press.

Johnson, J. L. (1973). Use of nucleic-acid homologies in the taxonomy of anaerobic bacteria. International Journal of Systematic Bacteriology 23, 308-3 I 5.

KING, E. O. (1959). Studies on a group of previously unclassified bacteria associated with meningitis in infants. American Journal of Clinical Pathology 31, 241-247.

LAPAGE, S. P. \& OWEN, R. J. (1973). Flavobacterium meningosepticum from cases of meningitis in Botswana and England. Journal of Clinical Pathology 26, 747-749.

MARMUR, J. (1961). A procedure for the isolation of deoxyribonucleic acid from micro-organisms. Journal of Molecular Biology 3, 208-218.

Marmur, J. \& DotY, P. (1962). Determination of the base composition of deoxyribonucleic acid from its thermal denaturation temperature. Journal of Molecular Biology 5, 109-118.

MCCARTHY, B. J. \& FARQUhAR, M. N. (1972). The rate of change of DNA in evolution. Brookhaven Symposia in Biology 23, I-4I.

McMeekin, T. A., Stewart, D. B. \& Murray, J. G. (1972). The Adansonian taxonomy and the deoxyribonucleic acid base composition of some Gram negative, yellow pigmented rods. Journal of Applied Bacteriology 35, I 29-I 37.

Mitchell, T. G., Hendrie, M. S. \& Shewan, J. M. (I969). The taxonomy, differentiation and identification of Cytophaga species. Journal of Applied Bacteriology 32, 40-50.

OWEN, R. J. \& LAPAGE, S. P. (1974). A comparison of strains of King's group Ilb of Flavobacterium (with Flavobacterium meningosepticum). Antonie van Leeuwenhoek 40, 255-264.

OWen, R. J. \& SNell, J. J. S. (I973). Comparison of group IIf with Flavobacterium and Moraxella. Antonie van Leeuwenhoek 39, 473-480.

Perry, L. B. (1973). Gliding motility in some non-spreading flexi-bacteria. Journal of Applied Bacteriology 36, 227-232.

SNell, J. J. S., Hill, L. R. \& LApage, S. P. (1972). Identification and characterization of Moraxella phenylpyruvica. Journal of Clinical Pathology 25, 959-965.

Sottile, M. I., Baldwin, J. N. \& Weaver, R. E. (1973). Deoxyribonucleic acid hybridization studies on Flavobacterium meningosepticum. Applied Microbiology 26, 535-539.

STUdier, F. W. (1965). Sedimentation studies of the size and shape of DNA. Journal of Molecular Biology II, 373-390.

SzYBALSKI, W. (1968). Use of cesium sulfate for equilibrium density gradient centrifugation. In Methods in Enzymology, vol. I 2 B, Nucleic Acids, pp. 330-360. Edited by L. Grossman and K. Moldave. London: Academic Press.

WeEks, O. B. (1974). Genus Flavobacterium Bergey et al. 1923. In Bergey's Manual of Determinative Bacterio$\log y$, 8th edn, pp. 357-364. Edited by R. E. Buchanan and N. E. Gibbons. Baltimore: Williams and Wilkins.

Wetmur, J. G. \& Davidson, N. (I968). Kinetics of renaturation of DNA. Journal of Molecular Biology 3I, 349-370.

ZadRAZIL, S., SATAVA, J. \& Sormova, Z. (1973). Isolation precedure for bactei ial DNA based on gel permeation chromatography on a sepharose column. Journal of Chromatography 91, 45 I-458. 